\title{
Halophilic Amylase Production and Purification from Haloarcula sp. Strain D61
}

\author{
Maryam Siroosi ${ }^{1}$ (D), Farshad Borjian Borujeni ${ }^{1}$, Mohammad Ali Amoozegar 1,* (D), Hamid Babavalian ${ }^{2}$, \\ Mehdi Hassanshahian ${ }^{3}$ id
}

1 Extremophiles Laboratory, Department of Microbiology, School of Biology and Center of Excellence in Phylogeny of Living Organisms, College of Science, University of Tehran, Tehran, Iran

2 Nanobiotechnology Research Center, Baqiyatallah University of Medical Sciences, Tehran, Iran

3 Department of Biology, Faculty of Sciences, Shahid Bahonar University of Kerman, Kerman, Iran

* Correspondence: amoozegar@ut.ac.ir;

Scopus Author ID 56742208100

Received: 25.05.2020; Revised: 13.06.2020; Accepted: 14.06.2020; Published: 16.06.2020

\begin{abstract}
The purpose of this study was the production and partial purification of amylase from a halophilic archaeon. The effect of different parameters on enzyme production and its activity was determined. An extracellular halophilic and moderately thermophilic amylase was produced under stress conditions in culture medium containing $23 \%$ salts by a newly isolated haloarchaeal strain, D61. The strain was identified, and the effect of $\mathrm{NaCl}, \mathrm{pH}$, temperature, and different nutrition factors on amylase production by the strain was examined. The enzyme was partially purified using gel filtration chromatography and then characterized. According to the biochemical and morphological characterization and analysis of the sequence of $16 \mathrm{~S}$ rRNA gene, the strain was identified as Haloarcula sp. strain D61. The strain was capable of producing amylase in the presence of $\mathrm{NaCl}$, and the maximum amylase production was at 3-4 $\mathrm{M} \mathrm{NaCl}$. Optimum temperature and $\mathrm{pH}$ for the enzyme production were detected to be $40-45^{\circ} \mathrm{C}$ and 7.0 , respectively. Among various carbon sources, maltose induced amylase production, while lactose, sucrose, and glucose repressed the production of the enzyme. $\mathrm{MgCl}_{2}$ was necessary for growth and amylase production by the strain, and no growth and enzyme production was observed in the absence of $\mathrm{MgCl} 2$. The optimum activity of the amylase was at $\mathrm{pH} 6.0$, temperatures of 35-40 ${ }^{\circ} \mathrm{C}$, and 3-5 M NaCl, as the amylase needs $\mathrm{NaCl}$ for its activity. Halophilic and moderate thermophilic amylases could be a good option for biotechnological applications or basic studies on enzyme structure to find differences between halophilic and mesophilic enzymes.
\end{abstract}

Keywords: Haloarcula; Amylase production; Extreme halophilic archaea; Halophiles.

(C) 2020 by the authors. This article is an open-access article distributed under the terms and conditions of the Creative Commons Attribution (CC BY) license (https://creativecommons.org/licenses/by/4.0/).

\section{Introduction}

Glycosyl hydrolases (amylases) are recognized extensively among the three domains of life: Eukarya, Bacteria, and Archaea. These enzymes are important members of the carbohydrate metabolism of different organisms and bacteria with antibacterial and anticancer properties. However, relatively few studies have focused on archaeal enzymes [1-5]. Alphaamylases convert starch and some other carbohydrates to simpler products by hydrolyzing $\alpha$ 1,4-glycosidic linkage in carbohydrates [6]. So, they can be used in various fields such as food, detergent, textile, and chemical industries, which need amylolytic enzymes to change starch into diverse sugar solutions [7]. Interests in enzyme production by halophilic microorganisms and their biotechnological requests have drawn more attention in recent years [8-10]. 
Although halophilic enzymes display enzymatic function similar to their non-halophilic counterparts, they show different biochemical properties such as activity and stability at high salt concentrations and in the presence of different organic solvents that make them appropriate biocatalysts for using in strict manufacturing procedures [11, 12]. Archaeal glycosyl hydrolases have received less attention in comparison with other domains. Production of glycosyl hydrolases, like amylases and xylanases, has been reported in some extremely halophilic archaea such as Haloarcula hispanica, Haloterrigena turkmenica, Halorubrum ezzemoulense, and Haloferax sulfurifontis [6, 13-15]. In the present work, production and partial purification of amylase from a newly isolated extremely halophilic archaeon, Haloarcula sp. strain D61 were investigated, and the effect of different factors on amylase production and its activity was studied.

\section{Materials and Methods}

\subsection{Chemicals.}

Sephadex G100, sugars, and BSB were purchased (Sigma-Aldrich). Culture medium ingredients, solvents, and salts were Merck products (Germany). Other chemicals were of analytical grade.

\subsection{Archaeal strain and culture conditions.}

Strain D61 was isolated from water samples of Aran-Bidgol (hypersaline lake, Iran) and cultured in Modified Growth Medium (MGM) containing $23 \%$ (w/v) total salts. In this medium, mineral salt base (containing (g/l): $\mathrm{NaCl}: 184, \mathrm{MgCl} 2.6 \mathrm{H} 2 \mathrm{O}: 23, \mathrm{MgSO} 4: 27, \mathrm{KCl}$ : 5.4, and $\mathrm{CaCl} 2: 4)$ was supplemented with $1 \%(\mathrm{w} / \mathrm{v})$ soluble starch, $1 \%(\mathrm{w} / \mathrm{v})$ meat peptone and $0.2 \%(\mathrm{w} / \mathrm{v})$ yeast extract. The $\mathrm{pH}$ was adjusted to 7.2-7.4. This modified medium was used for archaeal growth and amylase production experiments. The archaeon showed optimal growth at $45 \mathrm{oC}$ and identified as an extremely halophilic archaeon.

\subsection{Identification of the strain.}

The strain D61 was recognized according to biochemical tests and 16S rRNA gene sequencing analysis. Gram staining, motility test, ability to grow in anaerobic condition, and catalase and oxidase activities were performed according to related protocols. Indole formation, nitrate reduction, citrate utilization, and acid production from different carbohydrates (sucrose, ribose, mannose, glucose, lactose, maltose, fructose, galactose, and xylose) were checked [1620]). The ability of the strain to hydrolysis of tween 80 , casein, and gelatin were determined [21]. Also, $\mathrm{NaCl}$ concentration, $\mathrm{pH}$, and temperature ranges for the growth of the archaeal strain were determined. In order to $16 \mathrm{~S}$ rRNA gene sequencing, the Wan Lam method was used for the genomic DNA extraction of the strain D61 [22, 23]. The 16S rRNA gene of the strain was amplified with the universal primers $21 \mathrm{~F}$ (5'-TTCCGGTTGATCCYGCCGGA-3') and 1492R (5'-GGTTACCTTGTTACGACTT-3') and then were sequenced. After DNA sequencing, the sequence was compared to related 16S rRNA genes using EzTaxon-e server [24], and the phylogenic tree was made using MEGA 3 software. 


\subsection{Amylase production and crude enzyme preparation.}

Enzyme production was carried out by inoculating the modified medium in flasks with $1 \%(\mathrm{v} / \mathrm{v})$ of three days of archaeal culture. Cultures were incubated at $40 \mathrm{oC}$ on the shaker at $150 \mathrm{rpm}$. Flasks were removed after 7 days of incubation, and the contents were centrifuged at $9000 \mathrm{x} \mathrm{g}$ for $20 \mathrm{~min}$ at $4{ }^{\circ} \mathrm{C}$ to remove the archaeal cells, and the supernatant was considered as the crude amylase for amylase assays.

\subsection{Enzyme assay.}

The response combination was having $450 \mu \mathrm{l}$ of substrate solution $(1 \%(\mathrm{w} / \mathrm{v})$ soluble starch in $40 \mathrm{mM}$ Tris buffer ( $\mathrm{pH}$ 6.0) containing $3 \mathrm{M} \mathrm{NaCl}$ and $10 \mathrm{mM} \mathrm{CaCl}_{2}$ ), and $50 \mu \mathrm{l}$ of enzyme solution was incubated at $40{ }^{\circ} \mathrm{C}$ for $30 \mathrm{~min}$. The total of liberated reducing sugar was measured by the DNS method. To this purpose, $500 \mu \mathrm{l}$ of the DNS reagent was added to the mixture, and after 5 min incubation at $100{ }^{\circ} \mathrm{C}$, the absorbance of the solution was measured at $540 \mathrm{~nm}$ [25]. The control sample contained heat-inactivated amylase and was incubated at the same condition parallel to other samples. One unit of the amylolytic activity was defined as the amount of enzyme that releases $1 \mu \mathrm{mol}$ of reducing sugar per min.

2.6. Effect of temperature, $p H$, and salt concentrations on archaeal growth and amylase production.

To regulate the effect of temperature on growth and amylase production, the strain D61 was grown at a temperature range between $25-55{ }^{\circ} \mathrm{C}$. The effect of different $\mathrm{pH}$ values and different salts concentrations on the strain growth and enzyme production were studied by replacing suitable buffers $(50 \mathrm{mM})$ (glycine- $\mathrm{NaOH}$, sodium acetate; 6.0, Tris- $\mathrm{HCl}$; 9.0-11.0, MES; 7.0, HEPES; 8.0) with distilled water in the medium and using different concentrations of $\mathrm{NaCl}, \mathrm{Na}_{2} \mathrm{SO}_{4}, \mathrm{KCl}, \mathrm{NaCH}_{3} \mathrm{COOH}$, and $\mathrm{NaNO}_{3}$ (1-4 M), respectively. Different sodium salts $\left(\mathrm{Na}_{2} \mathrm{SO}_{4}, \mathrm{NaCH}_{3} \mathrm{COOH}\right.$, and $\left.\mathrm{NaNO}_{3}\right)$ and another salt contained chloride anion $(\mathrm{KCl})$ were replaced with $\mathrm{NaCl}$ in the medium and the results of growth and enzyme production were compared to those when $\mathrm{NaCl}$ was added to the medium. In this way, it could be possible to determine which ion (sodium or chloride) was important for strain growth and enzyme production. Effect of various concentrations of $\mathrm{MgCl}_{2}(0-0.4 \mathrm{M})$ on the growth and enzyme production was investigated in medium with $3.5 \mathrm{M} \mathrm{NaCl}$.

\subsection{Effect of carbon and nitrogen sources on archaeal cell growth and amylase production.}

To study the effect of different carbon sources on the growth and amylase production, the strain D61 was grown in the mineral salt medium ((w/v) $18.4 \% \mathrm{NaCl}, 2.7 \% \mathrm{MgSO}_{4} .7 \mathrm{H}_{2} \mathrm{O}$, $2.3 \% \mathrm{MgCl}_{2} .6 \mathrm{H}_{2} \mathrm{O}, 0.54 \% \mathrm{KCl}$, and $\left.0.058 \% \mathrm{CaCl}_{2} .2 \mathrm{H}_{2} \mathrm{O}\right)$ with various carbon and nitrogen sources. The different carbon sources containing soluble starch, lactose, dextrin, fructose, maltose, sucrose, and glucose were added at a concentration of $1 \%(\mathrm{w} / \mathrm{v})$ to the mineral salt medium. To determine the effect of several nitrogen-containing compounds on the growth and enzyme production by the strain D61, meat peptone, meat extract, yeast extract, $\mathrm{NH}_{4} \mathrm{Cl}$, $\left(\mathrm{NH}_{4}\right)_{2} \mathrm{SO}_{4}$, and $\mathrm{NaNO}_{3}$ were added at a concentration of $1 \%(\mathrm{w} / \mathrm{v})$ to the mineral salt medium. 


\subsection{Partial purification of the enzyme.}

The temperature was kept at $4{ }^{\circ} \mathrm{C}$ during the purification procedures. A 3-day old culture of the strain D61 was inoculated into $500 \mathrm{ml}$ MGM medium and incubated for 7 days at $40{ }^{\circ} \mathrm{C}$ on a rotary shaker operating at $150 \mathrm{rpm}$. The culture was centrifuged at $9000 \mathrm{x} \mathrm{g}$ for 20 min to remove the cells. To precipitate proteins, ethanol ( 0.8 volume) was gradually added to the supernatant, and then the mixture remained for $1 \mathrm{~h}$ at $4{ }^{\circ} \mathrm{C}$. The precipitated proteins were collected by centrifugation at $9000 \mathrm{x}$ g for $20 \mathrm{~min}$ and then dissolved in a minimum volume of $20 \mathrm{mM}$ Tris buffer ( $\mathrm{pH}$ 7.0) containing $3 \mathrm{M} \mathrm{NaCl}$. Insoluble matter was removed by centrifugation of the dissolved precipitate at $9000 \mathrm{x}$ g for $20 \mathrm{~min}$ and then was dialyzed $24 \mathrm{~h}$ against $20 \mathrm{mM}$ Tris buffer ( $\mathrm{pH} 7.0$ ) containing $3 \mathrm{M} \mathrm{NaCl}$ to remove any remaining ethanol from the protein solution. For further purification of the enzyme, the gel filtration method was performed using Sephadex G100 gel filtration column $(1 \times 40 \mathrm{~cm})$, equilibrated with $20 \mathrm{mM}$ Tris buffer ( $\mathrm{pH}$ 7.0) containing $3 \mathrm{M} \mathrm{NaCl}$. The proteins were eluted from the column by two column volumes of the same buffer at a flow rate of $0.2 \mathrm{ml} / \mathrm{min}$. The fractions with amylase activity were pooled together and used as the partially purified enzyme for further analysis. In all steps, protein concentrations were estimated according to the method of Bradford. The protein purity of the amylase was assessed by SDS-PAGE, as defined by Laemmli (data not shown) [26-29].

\subsection{Effect of $\mathrm{pH}$, temperature, and salt concentrations on the partially purified amylase.}

$\mathrm{pH}$ profile for partially purified amylase was detected under standard assay conditions in the range of 5.0-9.0, using the following buffers at a concentration of $20 \mathrm{mM}$ : 4.0-5.0, sodium acetate; 6.0, MES; 7.0-8.0, Tris- $\mathrm{HCl} ; 9.0-10.0$, glycine- $\mathrm{NaOH}$. The effect of temperatures between 10 and $60{ }^{\circ} \mathrm{C}$ on the partially purified enzyme activity was studied. The optimum concentration of $\mathrm{NaCl}$ for the amylolytic activity was determined by adding various concentrations of $\mathrm{NaCl}(0-5 \mathrm{M})$ to the enzymatic reaction mixture.

\subsection{Thin-layer chromatography.}

The response products from soluble starch as substrate produced by the amylase at different time intervals $(0.5,1,3$, and $24 \mathrm{~h})$ were exposed to thin-layer chromatography (TLC aluminum sheets silica gel 60F254). The productions on the TLC plate, advanced by multiple ascents with a solvent system of n-butanol-acetic acid-water $(3: 1: 1(\mathrm{v} / \mathrm{v} / \mathrm{v}))$ were detected by the method described by Pastuska [30, 31].

\section{Results and Discussion}

\subsection{Characteristics of the strain D61.}

The amylase producing strain was isolated from Aran-Bidgol (hypersaline lake, Iran). The strain D61 was Gram-stain-negative, pleomorphic shape, motile, and aerobic. The strain showed catalase and oxidase activity with the ability to reduce nitrate to nitrite, utilization of citrate, and hydrolysis of Tween 80 , gelatin, and casein. $\mathrm{H}_{2} \mathrm{~S}$ and indole were not produced. Among different carbohydrates, the strain could not produce acid from galactose and lactose. According to the biochemical and morphological characteristics of the strain D61 and data from 16S rRNA gene sequence analysis (about $1400 \mathrm{bps}$ were sequenced), the strain was recognized as Haloarcula sp. strain D61. The similar relative of strain D61 was Har. amylolytic 
BD-3T (DQ826513), as shown in the phylogenetic tree (Figure 1). Strain D61 was able to grow at $\mathrm{NaCl}$ concentration range of 2.0-5.2 $\mathrm{M}$, with optimal growth at $3.5 \mathrm{M}$. pH and temperature range for the archaeal strain growth was determined to be at 6.0-9.0 and 20-50 ${ }^{\circ} \mathrm{C}$, respectively with optimal values at $\mathrm{pH} 7.0$ and $40-45{ }^{\circ} \mathrm{C}$. Magnesium was necessary for growth with an optimum range of 0.2- 0.4 M. Differential characteristics of strain D61 and some related Haloarcula species are summarized in Table 1.

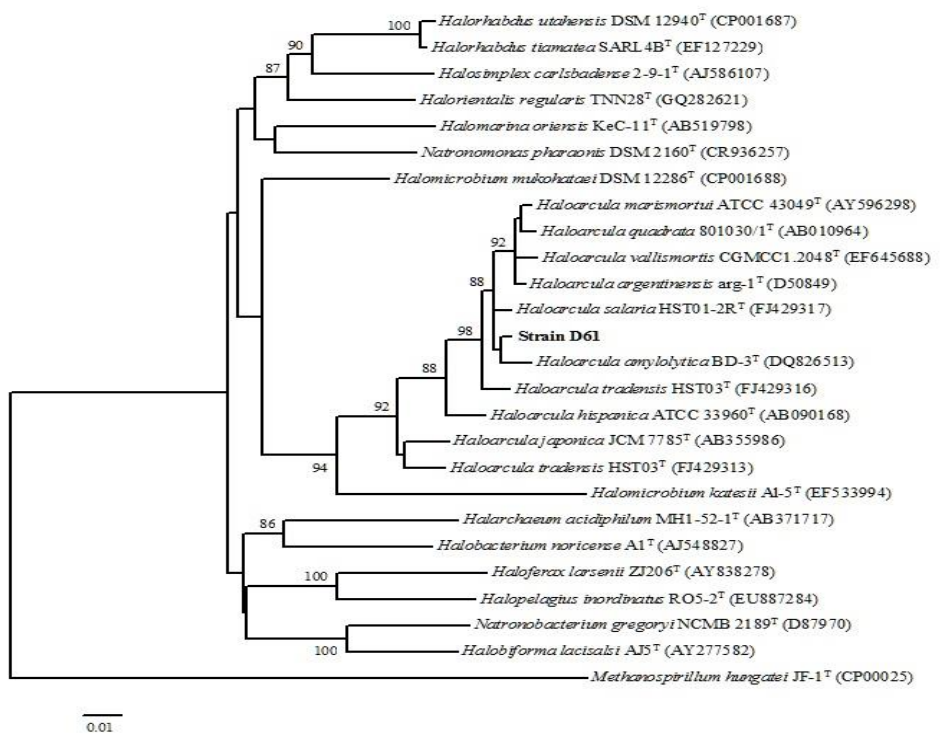

Figure 1. Neighbor-joining tree based on 16S rRNA gene sequencing analysis. Data from 16S rRNA gene sequencing showed that Har. amylolytica BD- $3^{\mathrm{T}}$ was the closest relative to strain D61. Phylogenetic relationship between the strain in the present study and other related strains is shown. The tree was constructed according to the Neighbour-joining algorithm. Bootstraps are given for each branch.

Table 1. Differential characteristics of strain D61 and some related Haloarcula species. 1. Strain D61; 2. Har. amylolytica (27); 3. Har. argentinensis (28); 4. Har. salaria (29); 5. Har. quadrata (30)

\begin{tabular}{l|l|l|l|l|l} 
Characteristic & $\mathbf{1}$ & $\mathbf{2}$ & $\mathbf{3}$ & $\mathbf{4}$ & $\mathbf{5}$ \\
\hline Cell shape & Pleomorphic shape & Rod & Triangular & Pleomorphic rods & square \\
\hline Hydrolysis of Tween 80 & + & + & + & + & - \\
\hline Gelatin liquefaction & + & + & + & - & - \\
\hline Indole formation & - & + & ND & ND & - \\
\hline Acid formation from sugars & + & \multicolumn{5}{l}{} \\
\hline D-glucose & - & - & + & - & - \\
\hline D-galactose & + & + & - & - \\
\hline Utilization of & + & + & ND & + \\
\hline Mannitol & + & + & - & ND & -
\end{tabular}

ND: No data available

3.2. Effect of Tm, pH, and different salts concentrations on the archaeal cell growth and amylase production.

The optimal temperature for growth and the amylase production were determined to be 40 and $45^{\circ} \mathrm{C}$, respectively (Figure $2 \mathrm{a}$ ). Both enzyme production and growth were at the highest level at $\mathrm{pH} 7.0$, with no growth at $\mathrm{pH}$ values of 4.0, 5.0, and 10.0 (Figure 2b). Among different tested $\mathrm{NaCl}$ concentrations, $3 \mathrm{M}$ of $\mathrm{NaCl}$ showed the best effect on cell growth and enzyme production, with no enzyme production at $2 \mathrm{M} \mathrm{NaCl}$ (Figure 2c). The optimum concentration of $\mathrm{MgCl}_{2}$ for amylase production and cell growth was $0.2 \mathrm{M}$ (Figure $2 \mathrm{~d}$ ). By replacement of $\mathrm{NaCl}$ with $\mathrm{KCl}$ and $\mathrm{Na} 2 \mathrm{SO} 4(1-4 \mathrm{M})$, the strain did not grow. In the case of $\mathrm{NaNO}_{3}$ and 
$\mathrm{NaCH}_{3} \mathrm{COOH}$, the growth without any amylase production was observed at a concentration of 4 and 3-4 M, respectively (Figure. 2e).

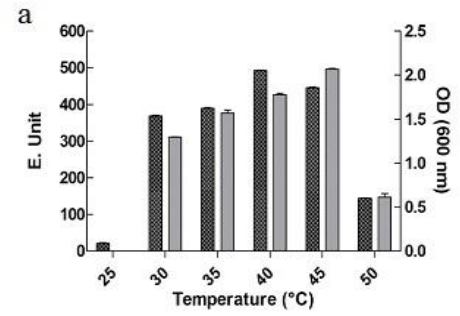

c

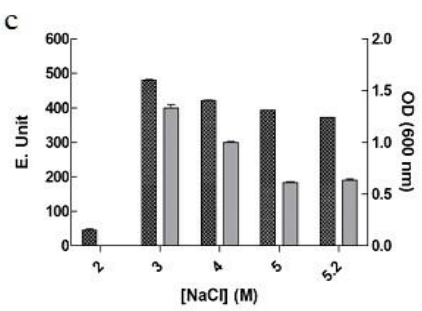

b

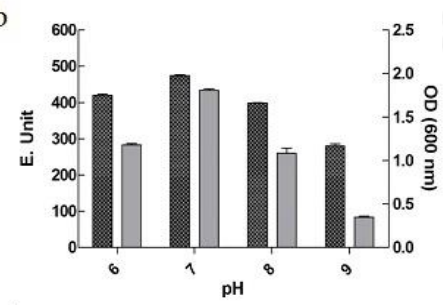

d

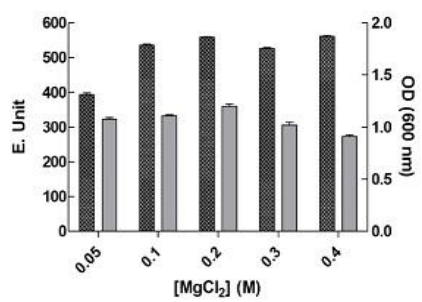

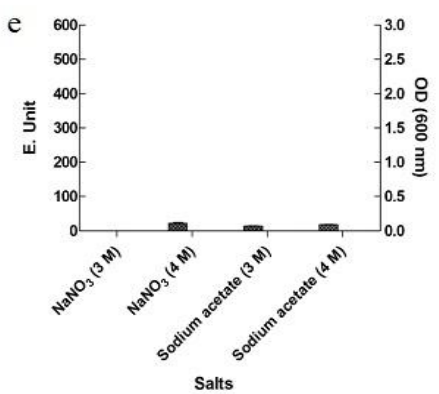

Figure 2. Effect of $\mathrm{pH}$, temperature, and different salts concentrations on growth and amylase production (black boxes: OD, grey boxes: Enzyme unit). A; Effect of temperature on growth and amylase production, b; Effect of $\mathrm{pH}$ on growth and amylase production. $\mathrm{C}$; Effect of different $\mathrm{NaCl}$ concentrations on growth and amylase production, d; Effect of different $\mathrm{MgCl}_{2}$ concentrations on growth and amylase production, e; Effect of different $\mathrm{NaNO}_{3}$ and $\mathrm{NaCH}_{3} \mathrm{COOH}$ concentrations on growth and amylase production.

a

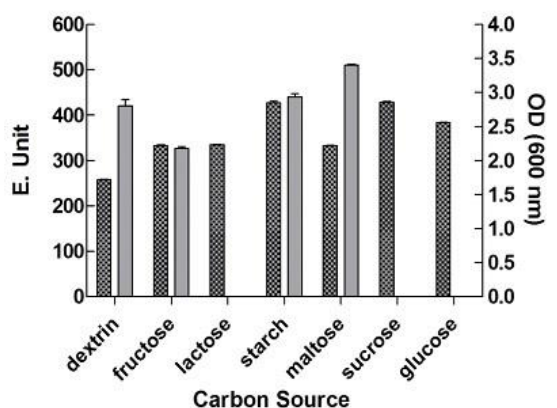

b

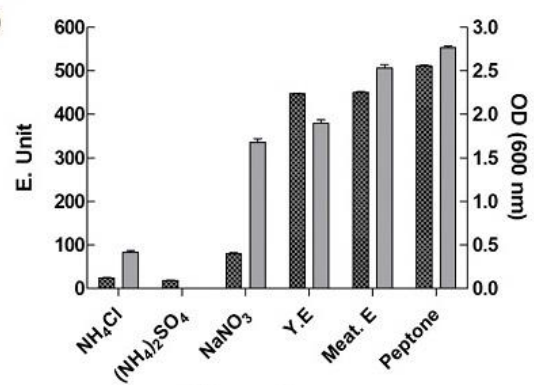

Nitrogen Source

Figure 3. Effect of different nutrient factors (carbon and nitrogen sources) on growth and amylase production by Haloarcula sp. strain D61. Enzyme activity was determined according to the mentioned standard method (black boxes: OD, grey boxes: Enzyme unit). a) Effect of carbon sources on growth and amylase production, b) Effect of nitrogen sources on growth and amylase production.

\subsection{Effect of carbon and nitrogen sources on the archaeal cell growth and amylase production.}

Among different studied carbon sources, maltose showed the best influence on amylase production and growth, while lactose, sucrose, and glucose inhibited amylase production. The maximum unit of the enzyme activity and the cell growth was observed using peptone as a nitrogen source. Amylase production was not supported by ammonium sulfate. The effect of 
different nutrient sources on the growth of the strain and amylase production is shown in Figure 3.

\subsection{Partial purification of the amylase.}

Extracellular amylase was partially purified by ethanol precipitation and size exclusion chromatography methods. Results from the purification of the amylase are summarized in Table 2. One sharp peak of amylolytic activity was eluted from a Sephadex G-100 column.

Table 2. Summary of the partial purification procedure of the amylase (ethanol precipitation and size exclusion chromatography methods). All purification procedures were performed at $4{ }^{\circ} \mathrm{C}$. All assays were done using Tris buffer (pH 6.0) containing $3 \mathrm{M} \mathrm{NaCl}$ and $10 \mathrm{mM} \mathrm{CaCl}_{2}$ at $40{ }^{\circ} \mathrm{C}$ for $30 \mathrm{~min}$.

\begin{tabular}{l|l|l|l|l} 
Purification step & $\begin{array}{l}\text { Total activity } \\
\text { (U) }\end{array}$ & Total protein & $\begin{array}{l}\text { Specific activity } \\
\text { (U/mg) }\end{array}$ & $\begin{array}{l}\text { Purification } \\
\text { (fold) }\end{array}$ \\
\hline Culture supernatant & 23800 & 8 & 2975 & 1 \\
\hline Ethanol precipitation & 1744 & 0.44 & 3963 & 1.3 \\
\hline Sephadex G-100 & 121 & 0.0086 & 14162 & 4.8
\end{tabular}

\subsection{Effect of different parameters on enzyme activity.}

The effect of different parameters on the amylolytic activity is shown in Fig. 4. The optimum $\mathrm{pH}$ for the enzyme activity was observed at $\mathrm{pH}$ 6.0, and the activity was reduced more than $90 \%$ at acidic $(\mathrm{pH} \mathrm{5.0)}$ and alkaline $(\mathrm{pH} 9.0) \mathrm{pH}$ values (Figure 4a). As shown in the temperature profile of the amylolytic activity (Figure 4b), optimum enzyme activity was observed at temperatures of $35-40{ }^{\circ} \mathrm{C}$. The effect of different $\mathrm{NaCl}$ concentrations on amylolytic activity is shown in Figure 4c. The amylolytic activity was observed in a salinity range of 0.5-5.0 M NaCl, with an optimum at 4-5 $\mathrm{M} \mathrm{NaCl}$. The enzyme did not show any activity at $0 \mathrm{M} \mathrm{NaCl}$.
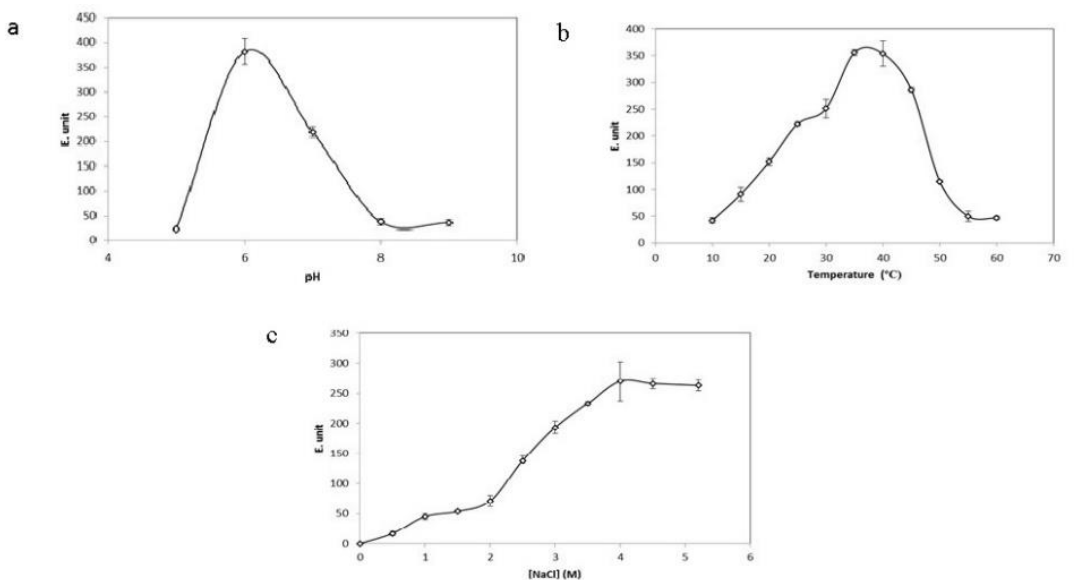

Figure 4. Effect of different parameters on the partially purified amylase activity. The enzyme activity was determined according to the mentioned standard method. a) Effect of $\mathrm{pH}$ on the amylase enzyme activity (from 5 to 9), b) Effect of temperature on amylase activity (from 10 to $60{ }^{\circ} \mathrm{C}$ ), c) Effect of $\mathrm{NaCl}$ concentrations on amylase activity (from 0 to $5 \mathrm{M}$ ).

3.6. Mode of action of the amylase.

TLC of the amylase products from soluble starch hydrolysis after $0.5,1,3$, and $24 \mathrm{~h}$ of assay mixture incubation at standard condition is shown in Fig. 5. The control sample contained heat-inactivated amylase and was incubated at the same condition parallel to other samples. The amylase hydrolyzed the substrate to maltotriose and maltotetraose with different 
concentrations at different time intervals. As seen in Figure 5, no sugar was present in the control sample, and sugar spots were very pale in the sample that was incubated for $0.5 \mathrm{~h}$. The spots are darker in the sample that was incubated for $1 \mathrm{~h}$ and even darker in other samples.

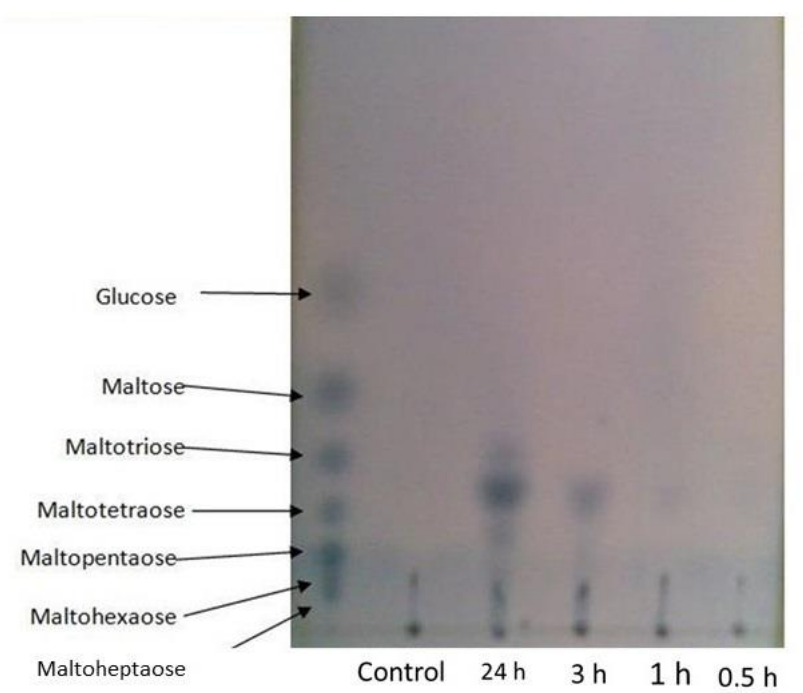

Figure 5. Action patterns of the amylase on soluble starch at different time intervals (after 0.5, 1, 3, and $24 \mathrm{~h}$ ). The enzymatic assay was performed according to the standard assay condition. A standard mixture of maltooligosaccharides (ranging from glucose (G1), maltose (G2), maltotriose (G3), maltotetraose (G3), maltopentaose (G5), maltohexaose (G6), and maltoheptaose (G7)) is represented on the left.

Halophilic microorganisms are able to adapt and live in a wide range of salinities that show their potential applications in different fields of biotechnology. In the present study, an amylase was produced in a culture medium containing $23 \%$ salts and showed its greatest activity in the presence of 3-5 $\mathrm{M}$ of $\mathrm{NaCl}$. It was found that amylase production by the strain was inductive, and maltose was the best inducer for enzyme production, like other microbial amylases. Maltose played a role as an inducer for the production of pullulanase and amylase by Rhodothermus marinus [32]. In the existence of sucrose and glucose as carbon sources in the medium, no amylase production by Haloarcula sp. strain D61 was detected. This catabolic repression mechanism has been described for extracellular enzyme production for another amylase from Micrococcus halobius OR1 [33].

Studies on the effect of different nitrogen sources on amylase production by the strain D61 and its growth revealed peptone as the best nitrogen source. In contrast, amylase production was not detected in the existence of ammonium sulfate. It may be due to the precipitation of proteins in the presence of this salt. Haloarcula sp. strain D61 is an extremely halophilic archaeon that cannot grow in a culture medium containing less than $2 \mathrm{M} \mathrm{NaCl}$, the fact that is true for other extremely halophilic archaea $[6,14]$. The strain showed optimum cell growth and enzyme production in the presence of $3 \mathrm{M} \mathrm{NaCl}$. These findings were predictable because Haloarcula sp. strain D61 was an extremely halophilic archaeon that needed $\mathrm{NaCl}$ for the stability of its membrane and proteins.

Like other halophilic archaea such as Har. argentinensis [34], Haloarcula sp. strain D61 was not able to grow without magnesium ions. This requirement for magnesium is because the ion is needed for cell wall stability and protein synthesis by halophilic archaea. It was showed that $\mathrm{NaCl}$ was necessary for amylase production, and by replacing $\mathrm{NaCl}$ with different salts, no amylase production was observed. The partially purified amylase needed $\mathrm{NaCl}$ for its activity and stability. The enzyme solution deactivated when dialyzed against buffer without 
$\mathrm{NaCl}$, which is shown in other reports $[6,14]$. , The maximum activity of the partially purified enzyme was in $4 \mathrm{M} \mathrm{NaCl}$, like amylase from Har. hispanica [14]. The reason for enzyme inactivation in the absence of $\mathrm{NaCl}$ is because of the special structure of the halophilic proteins. There are more acidic residues on the protein surfaces surrounded by hydrated ions that mean these kinds of enzymes need salt for their activity and stability.

Optimum $\mathrm{pH}$ value for the amylase activity was at $\mathrm{pH}$ 6.0, compared to other halophiles, which showed the maximum enzyme activity at alkaline $\mathrm{pH}$ range. According to the results, temperatures of $35-40{ }^{\circ} \mathrm{C}$ showed the best effect on the amylase activity from Haloarcula sp. strain D61. At lower and higher temperatures $\left(10\right.$ and $\left.55-60{ }^{\circ} \mathrm{C}\right), 10 \%$ of the initial enzyme activity were detected. The partially purified amylase from Haloarcula sp. strain D61 hydrolyzed soluble starch to maltotriose and maltotetraose as main products like amylase from Chromohalobacter sp. TVSP 101, but most amylases from other halophiles hydrolyze soluble starch to maltose and maltotriose [35, 36].

According to the present work, the amylase from Haloarcula sp. strain D61 is a good option for biotechnological and industrial purposes at extreme conditions like hydrolyzing the starch in effluents containing high salts concentration, especially in the form of immobilized Immubilization of enzymes is a great method to stabilize them [37]. Because of industrial applications, more attention has been drawn to halophilic amylases and other halophilic enzymes in recent years [38, 39, 40, 41, 42].

\section{Conclusions}

According to the present work, the amylase from Haloarcula sp. strain D61 is a good option for biotechnological and industrial purposes at extreme conditions like hydrolyzing the starch in effluents containing high salts concentration. The ability of Haloarcula sp. strain D61 to secrete high amounts of amylase into the medium containing $3 \mathrm{M} \mathrm{NaCl}$ (specific activity of $2975 \mathrm{U} / \mathrm{mg}$ ), a simple, easy method to partially purify the enzyme, the optimum activity at elevated temperatures $\left(40-45^{\circ} \mathrm{C}\right)$, and the nature of the produced hydrolysates (maltotriose and maltotetraose) are advantages of this enzyme compared to other regular amylases.

\section{Funding}

This work was supported by a grant from the Research Council of the University of Tehran.

\section{Acknowledgments}

We thank all colleagues.

\section{Conflicts of Interest}

The authors declare no conflict of interest.

\section{References}

1. Eichler, J. Biotechnological uses of archaeal extremozymes. Biotech Adv 2001, 19, 261-278, https://doi.org/10.1016/S0734-9750(01)00061-1.

2. Enache, M.; Kamekura, M. Hydrolytic enzymes of halophilic microorganisms and their economic values. Rom J Biochem 2010, 47, 46-59.

3. Seifi Kafshgari, H.; Yazdanian, M.; Ranjbar, R.; Tahmasebi, E.; Mirsaeed, S.; Tebyanian, H.; Ebrahimzadeh, M.A.; Goli, H.R. The effect of Citrullus colocynthis extracts on Streptococcus mutans, Candida albicans, 
normal gingival fibroblast and breast cancer cells. J Biol Res 2019, 92, https://doi.org/10.4081/jbr.2019.8201.

4. Khomarlou, N.; Aberoomand-Azar, P.; Lashgari, A.P.; Tebyanian, H.; Hakakian, A.; Ranjbar, R.; Ayatollahi, S.A. Essential oil composition and in vitro antibacterial activity of Chenopodium album subsp. striatum. Acta Biologica Hungarica 2018, 69, 144-155, https://doi.org/10.1556/018.69.2018.2.4.

5. Mosaddad, S.A.; Tahmasebi, E.; Yazdanian, A.; Rezvani, M.B.; Seifalian, A.; Yazdanian, M.; Tebyanian, H. Oral microbial biofilms: an update. Eur J Clin Microbiol 2019, https://doi.org/10.1007/s10096-01903641-9.

6. Pérez-Pomares, F.; Bautista, V.; Ferrer, J.; Pire, C.; Marhuenda-Egea, F.C.; Bonete, M.J. $\alpha$-Amylase activity from the halophilic archaeon Haloferax mediterranei. Extremophiles 2003, 7, 299-306, https://doi.org/10.1007/s00792-003-0327-6.

7. Souza, P.M.d. Application of microbial $\alpha$-amylase in industry-A review. Braz J Microbiol 2010, 41, 850861, https://doi.org/10.1590/S1517-83822010000400004.

8. Amoozegar, M.A.; Malekzadeh, F.; Malik, K.A. Production of amylase by newly isolated moderate halophile, Halobacillus sp. strain MA-2. J Microbiol Meth 2003, 52, 353-359, https://doi.org/10.1016/S0167-7012(02)00191-4.

9. Kakhki, A.M.; Amoozegar, M.A.; Khaledi, E.M. Diversity of hydrolytic enzymes in haloarchaeal strains isolated from salt lake. Int J Environ Sci Technol 2011, 8, 705-714, https://doi.org/10.1007/BF03326255.

10. Siroosi, M.; Amoozegar, M.A.; Khajeh, K.; Fazeli, M.; Rezaei, M.H. Purification and characterization of a novel extracellular halophilic and organic solvent-tolerant amylopullulanase from the haloarchaeon, Halorubrum sp. strain Ha25. Extremophiles 2014, 18, 25-33, https://doi.org/10.1007/s00792-013-0589-6.

11. Demirjian, D.C.; Morís-Varas, F.; Cassidy, C.S. Enzymes from extremophiles. Curr Opin Chem Biol 2001, 5, 144-151, https://doi.org/10.1016/S1367-5931(00)00183-6.

12. Madern, D.; Ebel, C.; Zaccai, G. Halophilic adaptation of enzymes. Extremophiles 2000, 4, 91-98, https://doi.org/10.1007/s007920050142.

13. Good, W.A.; Hartman, P.A. Properties of the amylase from Halobacterium halobium. J Bacteriol 1970, 104, 601-603,

14. Hutcheon, G.W.; Vasisht, N.; Bolhuis, A. Characterisation of a highly stable $\alpha$-amylase from the halophilic archaeon Haloarcula hispanica. Extremophiles 2005, 9, 487-495, https://doi.org/10.1007/s00792-005-04712 .

15. Wainø, M.; Ingvorsen, K. Production of $\beta$-xylanase and $\beta$-xylosidase by the extremely halophilic archaeon Halorhabdus utahensis. Extremophiles 2003, 7, 87-93, https://doi.org/10.1007/s00792-002-0299-y.

16. Dussault, H.P. An improved technique for staining red halophilic bacteria. J Bacteriol 1955, 70, 484,

17. Oren, A.; Ventosa, A.; Grant, W.D. Proposed minimal standards for description of new taxa in the order Halobacteriales. Int J Syst Bacteriol 1997, 47, 233-238, https://doi.org/10.1099/00207713-47-1-233.

18. Rezaeeyan, Z.; Safarpour, A.; Amoozegar, M.A.; Babavalian, H.; Tebyanian, H.; Shakeri, F. High carotenoid production by a halotolerant bacterium, Kocuria sp. strain QWT-12 and anticancer activity of its carotenoid. EXCLI J 2017, 16, 840-851, https://doi.org/10.17179/excli2017-218.

19. Tebyanian, H.; Mirhosseiny, S.H.; Kheirkhah, B.; Hassanshahian, M. Isolation and Identification of Mycoplasma synoviae From Suspected Ostriches by Polymerase Chain Reaction, in Kerman Province, Iran. Jundishapur J. Microbiol 2014, 7, https://doi.org/10.5812/jjm.19262.

20. Zarparvar, P.; Amoozegar, M.A.; Babavalian, H.; Reza, F.M.; Tebyanian, H.; Shakeri, F. Isolation and identification of culturable halophilic bacteria with producing hydrolytic enzyme from Incheh Broun hypersaline wetland in Iran. Cell Mol Biol (Noisy-le-grand) 2016, 62, 31-36, doi: 10.14715/cmb/2016.62.12.6.

21. Gutiérrez, C.; González, C. Method for simultaneous detection of proteinase and esterase activities in extremely halophilic bacteria. Appl Microbiol 1972, 24, 516.

22. Dyall-Smith, M. The Halohandbook: protocols for halobacterial genetics. Mark Dyall-Smith, Martinsried, Germany 2008.

23. Zolfaghar, M.; Amoozegar, M.A.; Khajeh, K.; Babavalian, H.; Tebyanian, H. Isolation and screening of extracellular anticancer enzymes from halophilic and halotolerant bacteria from different saline environments in Iran. Mol. Biol. Rep 2019, 46, 3275-3286, https://doi.org/10.1007/s11033-019-04787-7.

24. Kim, O.S.; Cho, Y.J.; Lee, K.; Yoon, S.H.; Kim, M.; Na, H.; Park, S.C.; Jeon, Y.S.; Lee, J.H.; Yi, H. Introducing EzTaxon-e: a prokaryotic 16S rRNA gene sequence database with phylotypes that represent uncultured species. Int J Syst Evol Microbiol 2012, 62, 716-721, https://doi.org/10.1099/ijs.0.038075-0.

25. Miller, G.L. Use of dinitrosalicylic acid reagent for determination of reducing sugar. Anal Chem 1959, 31 , 426-428, https://doi.org/10.1021/ac60147a030.

26. Bradford, M.M. A rapid and sensitive method for the quantitation of microgram quantities of protein utilizing the principle of protein-dye binding. Anal Biochem 1976, 72, 248-254, https://doi.org/10.1016/00032697(76)90527-3.

27. Laemmli, U.K. Cleavage of structural proteins during the assembly of the head of bacteriophage T4. Nature 1970, 227, https://doi.org/10.1038/227680a0. 
28. Heidari, M.F.; Arab, S.S.; Noroozi-Aghideh, A.; Tebyanian, H.; Latifi, A.M. Evaluation of the substitutions in 212, 342 and 215 amino acid positions in binding site of organophosphorus acid anhydrolase using the molecular docking and laboratory analysis. Bratisl Lek Listy 2019, 120, 139-143, https://doi.org/10.4149/bll_2019_022.

29. Taherian A; Fazilati M; Moghadam AT; Tebyanian, H. Optimization of purification procedure for horse F(ab')2 antivenom against Androctonus crassicauda (Scorpion) venom. Trop J Pharm Res 2018, 17, 409414, https://doi.org/10.4314/tjpr.v17i3.4.

30. Pastuska, G. Studies on the qualitative and quantitative determination of sugars by means of silica gel chromatography. Fresenius' Zeitschrift für analytische Chemie 1961, 179, 427-9.

31. Atarod, M.; Safari, J.; Tebyanian, H. Ultrasound irradiation and green synthesized CuO-NiO-ZnO mixed metal oxide: An efficient sono/nano-catalytic system toward a regioselective synthesis of 1-aryl-5-amino1H-tetrazoles. Synth. Commun 2020, 1-14, https://doi.org/10.1080/00397911.2020.1761396.

32. Gomes, I.; Gomes, J.; Steiner, W. Highly thermostable amylase and pullulanase of the extreme thermophilic eubacterium Rhodothermus marinus: production and partial characterization. Bioresour. Technol 2003, 90, 207-214, https://doi.org/10.1016/S0960-8524(03)00110-X.

33. Onishi, H. Halophilic amylase from a moderately halophilic Micrococcus. J Bacteriol 1972, 109, $570-574$.

34. Korcan, S.E.; Mutlu, M.B.; Ciğerci, İ.H.; Güven, K.; Konuk, M.; Kutlu, H.M. $\delta$-Aminolevulinic acid dehydratase of Haloarcula argentinensis isolated from Tuz Lake in Turkey. Environ Monit Assess 2010, 169, 229-236, https://doi.org/10.1007/s10661-009-1164-6.

35. Prakash, B.; Vidyasagar, M.; Madhukumar, M.S.; Muralikrishna, G.; Sreeramulu, K. Production, purification, and characterization of two extremely halotolerant, thermostable, and alkali-stable $\alpha$-amylases from Chromohalobacter sp. TVSP 101. Process Biochem 2009,44, 210-215, https://doi.org/10.1016/j.procbio.2008.10.013.

36. Shafiei, M.; Ziaee, A.A.; Amoozegar, M.A. Purification and characterization of an organic-solvent-tolerant halophilic $\alpha$-amylase from the moderately halophilic Nesterenkonia sp. strain F. J Ind Microbiol Biotechnol 2011, 38, 275-281, https://doi.org/10.1007/s10295-010-0770-1.

37. Sabae, Z. S., Eldourghamy, A. S., Aly, S. A., Rizk, N. M. H., Sobhy, A. Immobilization of lignin peroxidase from Alcaligenes aquatilisand its application in dye decolorization. Lett Appl NanoBioScience 2020, 9, 1058 -1063, https://doi.org/10.33263/LIANBS92.10581063.

38. Janeček, Štefan, and Barbora Zámocká. A new GH13 subfamily represented by the $\alpha$-amylase from the halophilic archaeon Haloarcula hispanica. Extremophiles 2020, 24, 207-217, https://doi.org/10.1016/S0022-2836(05)80360-2.

39. Shirodkar, Priyanka V., Muraleedharan, U. D., Damare, S.; Raghukumar, S. A Mesohaline Thraustochytrid Produces Extremely Halophilic Alpha-Amylases. Mar Biotechnol 2020, 14, 1-8, https://doi.org/10.1007/s10126-020-09960-9.

40. Pan, S., Yao, T., Du, L., Wei, Y.. Site-saturation mutagenesis at amino acid 329 of Klebsiella pneumoniae halophilic $\alpha$-amylase affects enzymatic properties. $J$ Biosci Bioeng 2020, 129, 155-159, https://doi.org/10.1016/j.jbiosc.2019.09.002.

41. Gaonkar, Sanket K., Irene J. Furtado. Characterization of Extracellular Protease from the Haloarcheon Halococcus sp. Strain GUGFAWS-3 (MF425611). Curr Microbiol 2020, 77, 1024-1034, https://doi.org/10.1007/s00284-020-01896-6.

42. Sharma, Amit K., Bhavtosh A. Kikani, Satya P. Singh. Biochemical, thermodynamic and structural characteristics of a biotechnologically compatible alkaline protease from a haloalkaliphilic, Nocardiopsis dassonvillei OK-18. Int J Biol Macromol 2020, 153, 680-696. 